ISSN: 0368-0797. Izvestiya VUZov. Chernaya Metallurgiya = Izvestiya. Ferrous Metallurgy. 2020. Vol. 63. No. 10, Pp. 836-841. (C) 2020. M.P. Kuz'min, M.Yu. Kuz'mina, Jia Q. Ran, A.S. Kuz'mina, A.E. Burdonov

UDC: $669.054 .8,661.66$

\title{
THE USE OF CARBON-CONTAINING WASTES OF ALUMINUM PRODUCTION IN FERROUS METALLURGY*
}

\author{
M.P. Kuz'min', Cand. Sci. (Eng.), Assist. Professor of the Chair "Non-Ferrous Metallurgy", \\ Deputy Head of the Chair "Metallurgy of Light Metals", Research Associate of Innovation and Technology Center \\ M.Yu. Kuz'mina1, Cand. Sci. (Eng.), Assist. Professor of the Chair "Non-Ferrous \\ Metallurgy" (kuzmina.my@yandex.ru)
}

Jia Q. Ran', PhD, Assist. Professor of College of Mechatronics and Control Engineering

A.S. Kuz'mina', Cand. Sci. (Phys.-Math.), Head of the Laboratory "Physical Properties

of Micro- and Nanostructures"

A.E. Burdonov", Cand. Sci. (Eng.), Head of the Laboratory "Mineral Processing

and Environmental Protection"

${ }^{1}$ Irkutsk National Research Technical University

(83 Lermontov str., Irkutsk, 664074, Russia)

${ }^{2}$ Shenzhen University

(3688, Nanhai Ave., Shenzhen, Guang Dong Province, 518060, China)

Abstract. The article discusses the prospects of recycling the most massive wastes of aluminum production (namely, used cathode blocks of electrolyzers, gas treatment dust, gas treatment residue, and flotation tailing). It have been indicated the volumes of wasteaccumulation and a special attention has been focused on the need of their disposal with a view to improve the environmental conditions of the territories adjacent to the industrial zones. Specific characteristics of the generated waste have been determined, which indicate the possibility of their secondary use and transfer from waste to by-products.Existing technical solutions relevant to the issue have been reviewed, and the reasons preventing their implementation have been explained. The most promising methods of waste processing to be carried out successfully in the current economic conditions have been identified. Spent cathode blocks can be used at ferrous metallurgy enterprises (in blast furnaces and converters) as a substitute for expensive coke and fluorspar, and finely dispersed waste can be used at cement enterprises. The areas have been determined that in the future will significantly increase the volume of processing and the demand for these wastes of the aluminum industry in technological processes of ferrous metallurgy. The possibilities for cooperation between aluminum refineries and ferrous metallurgy enterprises, as well as other related industries, were emphasized in detail.

Key words: aluminum production, waste, electrofilter dust, gas treatment residue, flotation tailings, cathode lining, cement production.

DOI: $10.17073 / 0368-0797-2020-10-836-841$

At present, the prospects of aluminum industry are closely connected to development of resource conservation and environmental technologies aimed at efficient processing of secondary materials and industrial waste utilization. Industrial waste of the aluminum industry constitutes about $20 \%$ of all the refuse generated in the production of nonferrous metals in Russia [1].

Currently, most of the aluminum is produced by electrolysis of cryolite-alumina melts in electrolyzers with self-baking Soderberg anodes. Waste materials typical for such a technology include electrofilter dust, gas treatment residue, flotation tailings as well as used cathode lining of electrolyzers. The issues pertaining to effective utilization of that waste have been repeatedly addressed in the scientific and technical literature [2-5].

For example, the work [3] discusses a technology that allows utilization of cathode lining of electrolyzers by sin-

\footnotetext{
* The research was financially supported by the grant for scientific and pedagogical collectives of Irkutsk National Research Technical University (project number 02-fpk-19).
}

tering the lining during the process of alumina production. The authors present a combination method of utilizing the lining where the pyrometallurgical process is followed by the leaching of the sintered products.

The mechanical method of utilizing the carbon part of the lining consists of subjecting the part to flotation with a view to obtain a fluorine concentrate which then is used in the electrolysis production of aluminum [4]. Likewise, for electrolyzers with Soderberg anodes, there exist techniques for introducing the carbon part of the lining into the anode mass [5]. However, the material costs associated with the preparation of the coal lining as well as its negative impact on the anode technology exceed the economic effect related to utilization of this type of waste.

Physical and chemical foundations of the carbonation method of regenerating fluorine from the used lining as well as the methods of intensification of the process are presented in [1]. The specialists of "SibVAMI", JSC, Irkutsk, made a great contribution to the development and implementation of this technology at Achinsk Alumina Refinery (ALR) $[1,2,5]$. 
The possibility of using fine materials of the slurry fields in production of cement is considered asthe most promising and economically feasible option [5]. Based on the studies conducted at Angarsk Cement Plant ("Angarskcement", JSC), an optimal amount of the fine materials additive introduced into the raw slurry was determined, and the economic effect of reducing the volume of conventional fuel used in the process was demonstrated.

The use of fluorocarbon-containing materials as a replacement for traditionally used fluorspar-based mineralizers in the process of obtaining Portland cement clinker is described in [6-10]. The authors examined the influence thatsuch types of waste have on the burning process of cement clinker and the quality of the final product. Comparative analysis of the microstructure of Portland cement clinker was also conducted, and the properties of the obtained cement (in accordance with GOST 310.4-81) were explored.

Among a wide variety of methods for processing and disposal of cathode blocks and fluorocarbon-containing arrays of the slurry fields, it is deemed essential to consider the techniques most suitable for large-scale implementation.

Used cathode hearth blocks are a lumpy dark gray mass with small pores (up to $0.2 \mathrm{~mm}$ ) which are quite uniformly filled with fluoride salts. The density of cathode blocks reaches $2.5 \mathrm{~g} / \mathrm{cm}^{3}$. Used cathode blocks are the main component of the waste generated by the aluminum industry as $10-12 \mathrm{~kg}$ of the refuse is produced per 1 ton of commercial aluminum [1]. Used cathode blocks can be partially utilized, and the valuable components may be returned to the process of aluminum production [11]. However, as a result of the change in the technology of electrolytic production of aluminum, most of the developments related to the return of valuable components $(\mathrm{Na}, \mathrm{Al}, \mathrm{F})$ in the electrolysis process has lost relevance. For instance, acidification of electrolytes in the aluminum electrolyzers led to a change in the balance of the consumption structure of fluorine and sodium compounds. There is a disproportion between the increased release of alkaline regenerative cryolite (because of the increased concentration of HF in the electrolysis gases due to the use of acid electrolytes) and its limited application in aluminum electrolysis. Therefore, the use of such waste materials in related industries is deemed rational.
Average chemical composition of the samples of used cathode lining is presented in Table 1 .

As seen, the fluorine content in the carbon blocks equals around $15 \%$, which is enough to ensure their successful application in ferrous metallurgy where various techniques are used to accelerate slag formation during steel smelting. It can also be achieved by introducing the materials reducing the slagmelting point into the charge. Fluorspar $\mathrm{CaF}_{2}$ is commonly used for that purpose, as its inclusion reduces the viscosity of the slag and ensures high process efficiency. However, as its natural reserves are limited, fluorspar is quite an expensive and scarce raw material. Hence, a wide range of natural and artificial materials containing fluorides of alkaline and alkaline earth metals, such as $\mathrm{NaF}, \mathrm{KF}$, $\mathrm{MgF}_{2}$, has been tested in ferrous metallurgy.

Coal blocks of used electrolyzers appear to be the most valid replacement of fluorspar. Due its bulk composition and sufficient mechanical strength, the blocks can be used inconverter without significant preparation $[12,13]$. When the fragments of the used blocks are heated, fluorine from cryolite and chiolite passes into thermally stable compounds $\mathrm{CaF}_{2}, \mathrm{CaO} \cdot 11 \mathrm{Al}_{2} \mathrm{O}_{3} \cdot 7 \mathrm{CaF}_{2}$, which perform the function of a fusible low-viscosity flux, and the burning carbon provides additional energy to the process.

Industrial tests of the coal blocks in converter were carried out at the West Siberian Metallurgical Plant ("ZSMK", JSC). A total of 45 pilot heats were conducted, which allowed to determine the methodology andto prove the feasibility of replacing fluorspar with the coal blocks [1]. The first pilotheatconfirmed the need for thorough preparation of the used blocks with regard to their fractional composition, as large pieces create difficulties during transportation along the existing supply routes of the charge materials. Besides, the ingress of large pieces of the blocks in converter in the last third of the blow process causes its intense combustion in slag even after the blow. That, in turn, leads to intense gas emission and incomplete assimilation of the carbon blocks by metallic and slag melts. The optimal fractional composition of the blocks $-20 \mathrm{~mm}$ to $80-100 \mathrm{~mm}$ - was determined empirically.

During the tests, it was discovered that to improve slag formation, it is advisable to ore down the most of the coal blocks at beginning of the blowing process. In that case, fluxing effect is slightly delayed in comparison with the use

Table 1

Chemical composition of the samples of used cathode lining

Таблица 1. Химический состав образцов отработанной катодной футеровки

\begin{tabular}{|c|c|c|c|c|c|c|c|c|c|c|c|}
\hline \multirow{2}{*}{$\begin{array}{l}\text { Components } \\
\text { of the lining }\end{array}$} & \multicolumn{11}{|c|}{ Elements and compounds, \%, mass. } \\
\hline & $\mathrm{F}$ & $\mathrm{Al}$ & $\mathrm{Na}$ & $\mathrm{SiO}_{2}$ & $\mathrm{Fe}_{2} \mathrm{O}_{3}$ & $\mathrm{SO}_{4}$ & $\mathrm{Ca}$ & $\mathrm{Mg}$ & Tar & $\begin{array}{c}\text { LOI } \\
\text { (loss-on-ignition) }\end{array}$ & $\mathrm{Al}_{4} \mathrm{C}_{3}$ \\
\hline Coal hearth blocks & 13.8 & 10.2 & 10.0 & 1.66 & 3.34 & 0.52 & 0.94 & 0.81 & 0.15 & 49.61 & 7.25 \\
\hline Coal side blocks & 14.8 & 8.2 & 12.0 & 1.40 & 1.33 & 1.00 & 2.07 & 1.25 & 0.15 & 38.80 & 2.60 \\
\hline
\end{tabular}


of fluorspar. Yet, the effect of oxides and fluorides of alkaline and alkaline-earth metals contained in the coal blocks is longer and more uniform, in contrast to the short-term effect of fluorspar.

Aluminum industry generates large volumes of fine fluorocarbon-containing waste. It includes gas treatment dust, gas treatment residue, and coal foam flotation tailings, which are formed in approximately equal volume of $10-12 \mathrm{~kg}$ per ton of commercial aluminum [1]. Average chemical composition of contents of the slurry field is presented in Table 2.

Generation and accumulation of this type of waste creates a serious problem for aluminum plants. For instance, the annual volume of waste stored in the slurry fields of four refineries located in Siberian Federal district (Irkutsk, Bratsk, Krasnoyarsk and Novokuznetsk aluminum plants) exceeds 70 thousand tons. The slurry fields at the refineries are close to being filled completely [7]. The formation of new slurry fields is problematic due to the complexity of land acquisition (namely, lack of available space in the immediate vicinity of refineries) and significant financial costs.

Fine fluorocarbon-containing dust is partially used in the process of burning cement clinker in the cement industry $[5,7,14]$. A number of cement factories are forced to work with so-called high-sintering/hard-to-produce raw materials. At these plants, fluorspar is commonly used to intensify the process of reactions in solid phases. A dustlike fraction from the slurry fields of aluminum refineries can serve as an adequate replacement for that material. At a given concentration, the dust mixture is easily mixed in the raw slurry preparation tanks for feeding to the kiln.
Besides, this additive produces a double effect - fluorine ions lower the melting point, and carbon, while burning, saves fuel, which significantly reduces the cost of the final product.

The impact fluorocarbon-containing additives have on the degree of decarbonization is displayed in Fig. 1.

Fig. 1 demonstrates the temperature dependence of the degree of calcium carbonate decompositionduring burning of the raw slurry (1) and the slurry with an additive (2) ( $0.1 \%$ equivalent to fluorine). The dependence is obtained by graphical and mathematical processing of the corresponding derivatograms. Fig. 1 shows that at the same temperatures the degree of $\mathrm{CaCO}_{3}$ decarbonization in the sample with an additive is $20-60 \%$ higher than in the sample consisting of the raw slurry, which automatically reduces the specific fuel consumption.

However, fine fluorocarbon-containing wastes of aluminum production have not been implemented into the cement industry on the large scale as such wastes contain sodium, and content of sodium in the final product is strictly regulated.

Since 2009, only Angarsk Cement Plant has been fully using fine fluorocarbon-containing materials. It was preceded by a long-term collaboration between cement technologists and metallurgists with a view to prepare all components of the raw slurry and determine the exact dosages of fluorocarbon-containing additives.

Numerous experiments conducted at Angarsk Cement Plant have determined that addition of fluorocarbon-containing dust in the amount of $0.15 \%$ (equivalent to fluorine) to the composition of the raw slurry increases sodium content in the outgoing clinker by $0.05-0.06 \%$ which is

Table 2

Chemical composition of the contents of slurry field

Таблица 2. Химический состав содержимого шламового поля

\begin{tabular}{|c|c|c|c|c|}
\hline \multicolumn{2}{|c|}{ Chemical composition, \% (wt.) } & \multicolumn{3}{|c|}{ Molecular composition, \% (wt.) } \\
\hline Element & $\begin{array}{c}\text { Element content } \\
\text { (average) }\end{array}$ & Compound & Formula & $\begin{array}{c}\text { Compound content } \\
\text { (average) }\end{array}$ \\
\hline $\mathrm{F}$ & 19.5 & Cryolite & $\mathrm{Na}_{3} \mathrm{AlF}_{6}$ & 11.05 \\
\hline $\mathrm{Al}$ & 11.6 & Chiolite & $\mathrm{Na}_{5} \mathrm{Al}_{3} \mathrm{~F}_{14}$ & 21.81 \\
\hline $\mathrm{Na}$ & 10.3 & Aluminum oxide & $\mathrm{Al}_{2} \mathrm{O}_{3}$ & 12,00 \\
\hline $\mathrm{Ca}$ & 0.85 & Calcium fluoride & $\mathrm{CaF}_{2}$ & 1.66 \\
\hline $\mathrm{Mg}$ & 0.2 & Magnesium fluoride & $\mathrm{MgF}_{2}$ & 0.33 \\
\hline $\mathrm{C}$ & 45.0 & Carbon & $\mathrm{C}$ & 45.0 \\
\hline $\mathrm{Fe}$ & 1.4 & Iron oxide & $\mathrm{Fe}_{2} \mathrm{O}_{3}$ & 2.00 \\
\hline $\mathrm{Si}$ & 0.25 & Silicon oxide & $\mathrm{SiO}_{2}$ & 0.54 \\
\hline $\mathrm{S}$ & 0.9 & Sodium sulphate & $\mathrm{Na}_{2} \mathrm{SO}_{4}$ & 4.00 \\
\hline Other & 10.0 & Other & - & 1.61 \\
\hline
\end{tabular}

Note: 1) particle size distribution: $85 \%$ (wt.) is a fraction of $0.2-0 \mathrm{~mm}$, class $0.2-1.0 \mathrm{~mm}$ - not more than $15 \%$ (wt.); 2) Moisture not more than $20 \%$ (wt.). 


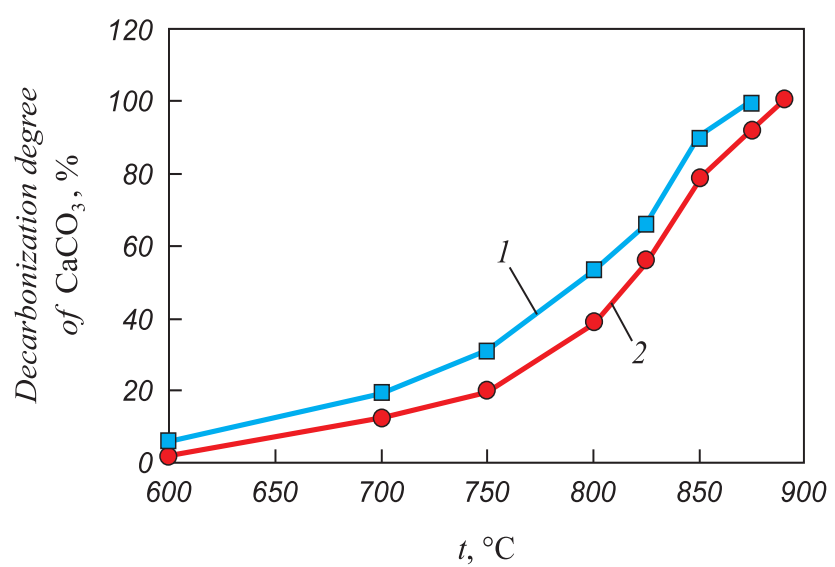

Fig. 1 Temperature dependence of the degree of $\mathrm{CaCO}_{3}$ decarbonization during the burning process:

1 - raw slurry; 2 - raw slurry + additive $0.10 \%$ (wt.) equivalent to fluorine

Рис. 1 Температурная зависимость степени декарбонизации $\mathrm{CaCO}_{3}$ при обжиге:

1 - индивидуальный сырьевой шлам;

2 - сырьевой шлам + добавка $0,10 \%$ (по массе) в пересчете на фтор

not considered critical. At the same time, rheological properties of the raw slurry have been improving, and the specific consumption of the conventional fuel has been reduced by $6 \mathrm{~kg} / \mathrm{t}$ ( $3 \%$ ). Besides, all the quality indicators of the obtained clinker are preserved. The experience of Angarsk Cement Plant can serve as an example for other cement factories that use fluorine-containing mineralizers.

Transformation of the dust fraction into durable briquettes, convenient for loading and transportation, could open the possibility for the large-scale use of the contents of the slurry fields in related industries (Fig. 2).

This material could be utilized in ferrous metallurgy both in converter processing (according to the scheme presented above) and in blast furnaces as a partial replacement of coke. It would also make possible to produce briquettes that could perform several functions simultaneously. For example, upon the addition of lime to the pulverized mixture, the resulting briquette could also serve as a desulfurizer. However, serious requirements are imposed on such briquettes in terms of their mechanical strength and moisture resistance.

Namely, the resulting briquettes should be able to:

- withstand three times the load when loaded with a mechanical shovel into cars; smalls formation not to exceed $9 \%$;

- absorb moisture not exceeding $8 \%$ when in the open; and

- the binders should not affect the functional properties of the additive.

The process of obtaining briquettes of a given quality constitutes separate work that has not been conducted until the present moment $[1,9,15-25]$. This work may be particularly important for enterprises engaged in the production of electrode, cathode and carbon graphite products,

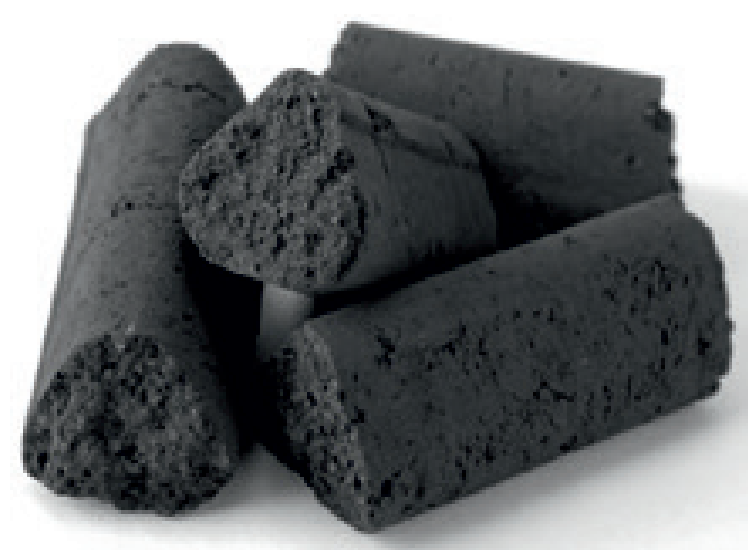

Fig. 2. Briquettes made of the pulverized waste

Рис. 2. Брикеты из пылевидных отходов

which also accumulate a significant amount of high calorie fine coal dust.

Conclusions. The use of cathode blocks in the field of ferrous metallurgy was established to be the most rational way of their utilization. The benefits for aluminum refineries are primarily associated with minimizing the cost of cathode blocks utilization; the advantages for ferrous metallurgy enterprises deal with the possibility of replacing expensive substances such as coke and fluorspar with cheap processed carbon-containing raw materials.

The use of fine waste of aluminum industry in the cement production was determined to be the most efficient way of handling such refuse. As the issue has been examined sufficiently, and the technology has been practically tested, successful disposal of fine waste of the aluminum production requires close cooperation between aluminum and cement plants in order to determine the needs and capabilities of the interested parties.

\section{REFERENCES}

1. Kulikov B.P. Istomin S.P. Pererabotka otkhodov alyuminievogo proizvodstva [Aluminum Waste Recycling]. SPb.: Izd-vo MANEB, 2004, 477 p. (In Russ.).

2. Kondrat'ev V.V., Rzhechitskii E.P., Shakhrai S.G., Karlina A.I., Sysoev I.A. Recycling of electrolyzer spent carbon-graphite lining with aluminum fluoride regeneration. Metallurgist. 2016, no. 5-6, pp. 571-575.

3. Gu Yanxin etc. Recycling and re-use of a spent cell base: Practice of usage in China. Light Metals. 1994, no. 5, pp. 269-273.

4. Borisoglebskii Yu.V., Bezrukov V.A., Vetyukov M.M. Effect of additives of aluminum electrolyzers spent lining to anode mass on anode consumption. Tsvetnye metally. 1996, no. 8, pp. 37-39. (In Russ.).

5. Kulikov B.P., Barinov V.V., Nikolaev M.D., Pyrkova I.V., Shuvalova S.A. Disposal of fluorine-containing waste from aluminum production in cement industry. Ekologiya i promyshlennost' Rossii. 2010, no. 5, pp. 4-6. (In Russ.).

6. Kondrat'ev V.V., Nemchinova N.V., Ivanov N.A., Ershov V.A., Sysoev I.A. New production solutions for processing silicon and aluminum production waste. Metallurgist. 2013, no. 5-6, pp. 455-459.

7. Kulikov B.P., Nikolaev M.D., Kuznetsov A.A., Barinov V.V., Pyrkova I.V. Obtaining clinker using a fluorine-based waste mineralizer. Tsement i ego primenenie. 2010, no. 2, pp. 102-105. (In Russ.). 
8. Kuz'min M.P., Larionov L.M., Kondratiev V.V., Kuz'mina M.Yu., Grigoriev V.G., Kuz'mina A.S. Use of the burnt rock of coal deposits slag heaps in the concrete products manufacturing. Construction and Building Materials. 2018, vol. 179, pp. 117-124.

9. Nath S.K., Sanjay Kumar. Evaluation of the suitability of ground granulated silico-manganese slag in Portland slag cement. Construction and Building Materials. 2016, vol. 125, pp. 127-134.

10. Davoud Tavakoli, Amir Tarighat. Molecular dynamics study on the mechanical properties of Portland cement clinker phases. Computational Materials Science. 2016, vol. 119, pp. 65-73.

11. Brough D., Jouhara H. The aluminium industry: A review on stateof-the-art technologies, environmental impacts and possibilities for waste heat recovery. Int. Journal of Thermofluids. 2020, vol. 1-2, article 100007

12. Nazyuta L.Yu., Starovoit A.G. Analysis of the raw material base of metallurgical production. Metallurgiya i koksokhimiya. 1979, no. 63, pp. 19-22. (In Russ.).

13. Demidov K.N. Preliminary heating of scrap in converter with cobbed carbon-containing fuel. Stal'. 1987, no. 5, pp. 27-30. (In Russ.).

14. Agrawal A., Sahu K.K., Pandey B.D. Solid waste management in non-ferrous industries in India. Resources, Conservation and Recycling. 2004, vol. 42, no. 2, pp. 99-120.

15. Kuz'mina M.Yu., Kuz'min P.B. On the production of ingots of primary silumin modified by strontium. Liteinoe proizvodstvo. 2014, no. 8, pp. 2-5. (In Russ.).

16. Anfilogova L.A., Belousova O.V., Kuz'mina M.Yu., Bogidaev S.A. Effective technologies in processing of rare earth raw materials. Tsvetnaya metallurgiya, 2005, no 2, pp. 17-21. (In Russ.).

17. Fedorov S.N., Kurtenkov R.V., Vasiliev V.V. Stabilization $\mathrm{TiO}_{2}$ anatase by F-ion doping for solar panel producing. Journal of Physics. Conference Series. 2018, vol. 1124, no. 4, article 041026.
18. Kondratiev V.V., Rzhechitskiy E.P., Bogdanov Y.V., Sysoev I.A., Karlina A.I. Technology of the thermal extraction of fluorosols from spent refractory lining. Int. Journal of Applied Engineering Research. 2017, vol. 12, no. 23. pp. 13812-13819.

19. Gorlanov E.S., Bazhin V.Yu., Fedorov S.N. Carbide formation at a carbon-graphite lining cathode surface wettable with aluminum. Refractories and Industrial Ceramics. 2016, vol. 57, no. 3, pp. 292-296.

20. Florentino-Madiedo L., Díaz-Faes E., Barriocanal C. Reactivity of biomass containing briquettes for metallurgical coke production. Fuel Processing Technology. 2019, vol. 193, pp. 212-220.

21. Zenkov E.V., Tsvik L.B. The formation of differently directed test forces and experimental evaluation of material strength under biaxial stretching. PNRPU Mechanics Bulletin. 2018, no. 1-2, pp. 71-76.

22. Jagmeet Singh, Singh S.P. Geopolymerization of solid waste of nonferrous metallurgy - A review. Journal of Environmental Management. 2019, vol. 251, article 109571.

23. Zenkov E.V. Update of the equations of the limit state of the structural material with the realization of their deformation. Journal of Physics: Conference Series. 2017, vol. 944, article UNSP012128.

24. Zenkov E.V., Tsvik L.B. Increasing the reliability the combined criteria of the static strength of a material of complexly loaded deformable structures. Materials Physics and Mechanics. 2018, vol. 40, no. 1, pp. 124-132.

25. Diez M.A., Alvarez R., Cimadevilla J.L.G. Briquetting of carboncontaining wastes from steelmaking for metallurgical coke production. Fuel. 2013, vol. 114, pp. 216-223.

Received January 23, 2020 Revised May 20, 2020 Accepted October 16, 2020

ИЗВЕСТИЯ ВЫСШИХ УчЕБНЫХ ЗАВЕДЕНИЙ. ЧЕРНАЯ мЕТАЛЛУРГИЯ. 2020. Том 63. № 10. С. 836-841.

\section{ИСПОЛЬЗОВАНИЕ УГЛЕРОДСОДЕРЖАЩИХ ОТХОДОВ ПРОИЗВОДСТВА АЛЮМИНИЯ В ЧЕРНОЙ МЕТАЛЛУРГИИ}

\author{
Кузьмин М.П.', Кузьмина М.Ю. ${ }^{1}$, Джниа Ку. Ран ${ }^{2}$, Кузьми- \\ на $A . C^{1}$, Бурдонов $A$. . $^{1}$
}

\section{${ }^{1}$ Иркутский национальный исследовательский технический уни- верситет (664074, Россия, Иркутск, ул. Лермонтова, 83) ${ }^{2}$ Шэньчжэньский университет (518060, Китай, провинция Гуан Донг, Шеньжень, пр. Наньхай, 3688)}

Аннотация. Представлены наиболее масштабные виды отходов алюминиевого производства (отработанные катодные блоки электролизеров, пыль газоочистки, шламы газоочистки, хвосты флотации угольной пены). Обозначены объемы их накопления и акцентировано внимание на необходимости их утилизации для улучшения экологической обстановки прилегающих к предприятиям территорий. Определены специфические характеристики образовавшихся отходов, указывающие на возможность их вторичного использования и перевода из разряда отходов в побочные продукты. Рассмотрены возможности переработки, проведен обзор существующих по данному направлению технических решений, а также объяснены причины, препятствующие их реализации. Определены наиболее перспективные способы переработки отходов, реализацию которых можно произвести в существующих экономических условиях. Отработанные катодные блоки могут быть использованы на предприятиях черной металлургии (в доменных печах и конвертерах) в качестве замены дорогостоящего кокса и плавикового шпата, а мелкодисперсные отходы - на предприятиях цементной промышленности. Обозначены направления, которые в будущем позволят существенно увеличить объемы пе- реработки, повысить востребованность указанных отходов алюминиевой промышленности в технологических переделах черной металлургии. Несмотря на то, что особое внимание уделено перспективам сотрудничества алюминиевых заводов с предприятиями черной металлургии, показаны примеры уже внедренных решений по совершенствованию сырьевой базы в других смежных отраслях промышленности.

Ключевые слова: алюминиевое производство, отходы, пыль электрофильтров, шлам газоочистки, хвосты флотации, катодная футеровка, производство цемента.

DOI: $10.17073 / 0368-0797-2020-10-836-841$

\section{БИБЛИОГРАФИЧЕСКИЙ СПИСОК}

1. Куликов Б.П. Истомин С.П. Переработка отходов алюминиевого производства - СПб.: Изд-во МАНЭБ, 2004. - 477 с.

2. Кондратьев В.В., Ржечицкий Э.П., Шахрай С.Г. и др. Переработка отработанной углеграфитовой футеровки электролизеров с регенерацией фтористого алюминия // Металлург. 2016. № 6 . C. $28-31$

3. Gu Yanxin etc. Recycling and re-use of a spent cell base: Practice of usage in China // Light Metals. 1994. No. 5. P. $269-273$.

4. Борисоглебский Ю.В., Безруков В.А., Ветюков М.М. Влияние добавок отработанной футеровки алюминиевых электролизеров в анодную массу на расход анода // Цветные металлы. 1996. № 8. C. $37-39$.

5. Куликов Б.П., Баринов В.В., Николаев М.Д. и др. Утилизация фторсодержащих отходов алюминиевого производства в це- 
ментной промышленности // Экология и промышленность России. 2010. № 5. С. $4-6$.

6. Кондратьев В.В., Немчинова Н.В., Иванов Н.А. и др. Новые технологические решения по переработке отходов кремниевого и алюминиевого производств // Металлург. 2013. № 5. С. 92 - 95.

7. Куликов Б.П., Николаев М.Д., Кузнецов А.А. и др. Получение клинкера с использованием минерализатора на основе фторсодержащих отходов // Цемент и его применение. 2010. № 2. C. $102-105$.

8. Kuz'min M.P., Larionov L.M., Kondratiev V.V. etc. Use of the burnt rock of coal deposits slag heaps in the concrete products manufacturing // Construction and Building Materials. 2018. Vol. 179. P. $117-124$.

9. Nath S.K., Sanjay Kumar. Evaluation of the suitability of ground granulated silico-manganese slag in Portland slag cement // Construction and Building Materials. 2016. Vol. 125. P. $127-134$.

10. Davoud Tavakoli, Amir Tarighat. Molecular dynamics study on the mechanical properties of Portland cement clinker phases // Computational Materials Science. 2016. Vol. 119. P. 65 - 73.

11. Brough D., Jouhara H. The aluminium industry: A review on stateof-the-art technologies, environmental impacts and possibilities for waste heat recovery // Int. Journal of Thermofluids. 2020. Vol. 1 -2. Article 100007.

12. Назюта Л.Ю., Старовойт А.Г. Анализ сырьевой базы металлургического производства // Металлургия и коксохимия. 1979. Вып. 63. С. $19-22$.

13. Демидов К.Н. Предварительный нагрев лома в конвертере кусковым углеродсодержащим топливом // Сталь. 1987. № 5. C. $27-30$.

14. Agrawal A., Sahu K.K., Pandey B.D. Solid waste management in non-ferrous industries in India // Resources, Conservation and Recycling. 2004. Vol. 42. No. 2. P. 99 - 120.

15. Кузьмина М.Ю., Кузьмин П.Б. О производстве чушек первичных силуминов, модифицированных стронцием // Литейное производство. 2014. № 8. С. 2 - 5.

16. Анфилогова Л.А., Белоусова О.В., Кузьмина М.Ю., Богидаев С.А. Эффективные технологии при переработке редкоземельного сырья и материалов // Изв. вуз. Цветная металлургия. 2005. № 2. C. $17-21$.

17. Fedorov S.N., Kurtenkov R.V., Vasiliev V.V. Stabilization $\mathrm{TiO}_{2}$ anatase by F-ion doping for solar panel producing // Journal of Physics: Conference Series. 2018. Vol. 1124. No. 4. Article 041026.

18. Kondratiev V.V., Rzhechitskiy E.P., Bogdanov Y.V. etc. Technology of the thermal extraction of fluorosols from spent refractory lining // Int. Journal of Applied Engineering Research. 2017. Vol. 12. No. 23. P. $13812-13819$.
19. Gorlanov E.S., Bazhin V.Yu., Fedorov S.N. Carbide formation at a carbon-graphite lining cathode surface wettable with aluminum // Refractories and Industrial Ceramics. 2016. Vol. 57. No. 3. P. $292-296$.

20. Florentino-Madiedo L., Díaz-Faes E., Barriocanal C. Reactivity of biomass containing briquettes for metallurgical coke production // Fuel Processing Technology. 2019. Vol. 193. P. 212 - 220.

21. Zenkov E.V., Tsvik L.B. The formation of differently directed test forces and experimental evaluation of material strength under biaxial stretching // PNRPU Mechanics Bulletin. 2018. No. 1-2. P. 71 - 76.

22. Jagmeet Singh, Singh S.P. Geopolymerization of solid waste of non-ferrous metallurgy - A review // Journal of Environmental Management. 2019. Vol. 251. Article 109571.

23. Zenkov E.V. Update of the equations of the limit state of the structural material with the realization of their deformation // Journal of Physics: Conference Series. 2017. Vol. 944. Article UNSP012128.

24. Zenkov E.V., Tsvik L.B. Increasing the reliability the combined criteria of the static strength of a material of complexly loaded deformable structures // Materials Physics and Mechanics. 2018. Vol. 40. No. 1. P. $124-132$.

25. Diez M.A., Alvarez R., Cimadevilla J.L.G. Briquetting of carboncontaining wastes from steelmaking for metallurgical coke production // Fuel. 2013. Vol. 114. P. 216 - 223.

Финансирование. Исследование выполнено за счет гранта по финансовой поддержке научно-педагогических коллективов ИРНИТУ (проект № 02-ФПК-19).

\section{Информация об авторах:}

Кузьмин М.П., к.т.н., доцент кафедры «Металлургия иветных металлов», зам. заведующего кафедрой «Металлургия легких металлов», научный сотрудник инновационно-технологического центтра

Кузьмина М.Ю., к.т.н., доиент кафедры «Металлургия ичветных металлов» (kuzmina.my@yandex.ru)

Джиа Ку. Ран, PhD, дочент колледжа мехатроники и управления Кузьмина А.С., к.ф.-м.н., научный руководитель лаборатории физических свойств микро- и наноструктур

Бурдонов А.Е., к.т.н., научный руководитель лаборатории обогащения полезных ископаемых и охраны окружающей среды

Поступила в редакцию 23 января 2020 г. После доработки 20 мая 2020 г.

Принята к публикации 16 октября 2020 г. 